\section{Mortality by Cancer as a Function of Age}

If $n$ independent, constantly active external causes, each producing some persistent damage, were required to bring about cancer, one would expect a mortality $(m)$ proportional to $t^{n}$, if $t$ is the age; i.o.w. one would expect a linear relationship between $\log m$ and $\log t$.

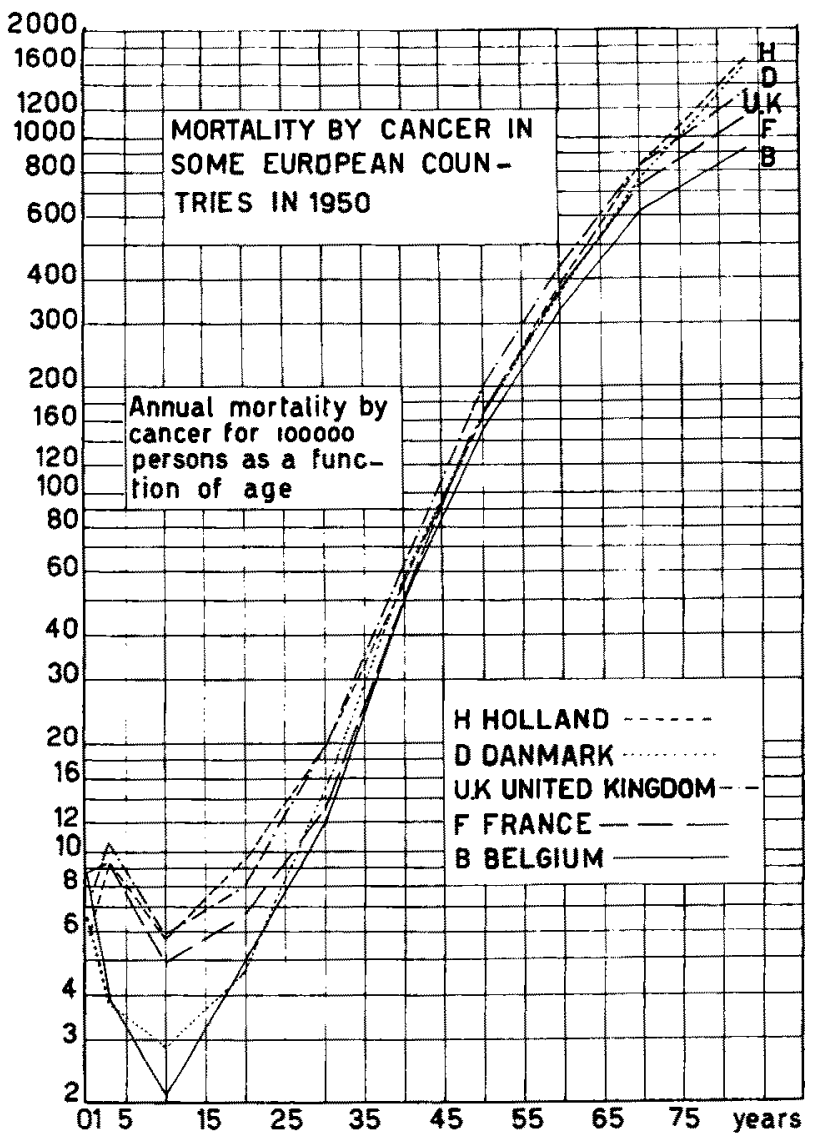

In order to test this hypothesis I called upon the "Belgisch Nationaal Werk voor de stryd tegen de kanker" to whom I gladly express my sincere gratitude, to provide me with some tables giving the mortality by. cancer as a function of age; the figures for Belgium, Holland, France, the United Kingdom and Denmark for 1950 are presented in the graph; they show a linear relationship ${ }^{1}$, not between $\log m$ and $\log t$, as expected, but between $\log m$ and $t$; for the time being, we consider only the right part of the curve; this curve

$$
\log m=a^{\prime} t+b^{\prime} ; \ln m=a t+b ; d m / d t=a m
$$

indicates that the mortality increases with age, and that the rate of this increase is proportional to the existing mortality, exactly as the rate of increase of a capital is proportional to this capital.

In order to give an interpretation of this result, let us assume that we may replace the mortality in the collectivity by the probability of death for its individual members. Then eq. (1) indicates that the rate of increase of this probability is proportional to the existing probability. This suggests that a material factor, capable of reproduction, is responsible for the disease (e.g. by making the cells of the body susceptible to it). This factor triples every 10 years, or doubles every 6.3 years. This process

1 With respect to the slight deviation from linearity, cf. note ${ }^{2}$. seems to go on uninterruptedly between puberty and old age ${ }^{2}$.

If we now consider the left part of the curve, it suggests that in new-born babies the factor is of the same magnitude as in their mothers ( 30 years old); during the first 10 years there is a sharp decrease (the factor is destroyed in the body), which is succeeded by a sharp increase after puberty.

The period for doubling, $6 \cdot 3$ years, may seem very long; but Dr SANDVED, Bergen. Norway, has informed me that the death of chimney-sweepers, caused by cancer, as a rule occurred 20 or 30 years after they had given up their work.

Let us end with a critical remark:

Mortality due to other death causes also shows a decline between birth and puberty, and a continuous rise afterwards, and we do not think of ascribing this state of affairs to a material factor; we should like to point out, however, that after deducting all deaths caused by diseases of known ethiology, we are left with a great number the causes of which are less well understood. It may be that one day a theory is found to apply to these cases which has some features in common with the reasoning given here.

\section{A. J. RUTGERS}

Laboratory for Physical Chemistry, Faculty of Science, University of Gent (Belgium), August 3, 1953.

\section{Résumé}

Le logarithme de la mortalité par cancer, entre la puberté et la vieillesse, est une fonction presque linéaire de l'âge. La mortalité est doublée tous les 6,3 ans. Cette progression nous mène à la conception que la sensibilité au cancer serait déterminée par la concentration d'un facteur matériel qui se reproduit.

2 The rate of reproduction depends of course on the state of the human body; this can easily explain the somewhat lower rate of reproduction before 30 and after 60 years, i.o.w. the slight deviation from linearity of the curve.

\section{PRO DOCENDO}

\section{Eine Vorrichtung zum schnellen Wechsel von Filmszenen (in beliebiger Folge)}

Bei biologischen und physikalisch-technischen Vorträgen oder Vorlesungen, die durch Filme (Laufbilder) erläutert werden, und bei denen man schnell verschiedene Bewegungsabläufe in wechselnder Folge vorzeigen will, wird die Umständlichkeit in der Handhabung normaler Filmprojektionen und das Gebundensein an eine feste Szenenfolge ebenso wie die Unmöglichkeit, eine kurze Szene ohne Pause mehrfach zu wiederholen, oft als sehr störend empfunden. Im folgenden sei daher das Prinzip einer durch einen Griff auswechselbaren Filmkassette kurz beschrieben, die Szenen bis zu mehreren Metern aufnimmt und, da Anfang und Ende des Streifens zu einer Schleife verbunden sind, auch ohne Pause wiederholen lässt. (Die Vorrichtung ist einem SiemensSchmalfilm-Projektor angepasst; bei anderen Typen dürften kleine Abwandlungen der Bauweise erforderlich sein.)

Abbildung 1 zeigt die Kassette, in deren Innerem der Film, je nach seiner Länge, in eine grössere oder kleinere Zahl Windungen gelegt ist, während er aus einer Schneckenführung $S$ heraus- und durch eine Öffnung $O$ in der äusseren Wand wieder hereintritt. Jede Filmszene 